\title{
THE ORIGINE AND EVOLUTION OF COASTAL AND SUBMARINE SPRINGS IN BAKAR BAY
}

\section{NASTANEK IN RAZVOJ OBALNIH IN PODMORSKIH IZVIROV V BAKARSKEM ZALIVU}

ČEDOMIR BENAC ${ }^{1} \&$ JOSIP RUBINIĆ $^{1} \&$ NEVENKA OŽANIĆ ${ }^{1}$

${ }^{1}$ University of Rijeka, Faculty of Civil Engineering, 51000 RIJEKA, V.Cara-Emina 5, CROATIA e-mail: benac@gradri.hr

Prejeto / received: 31. 1. 2003 


\section{Abstract \\ UDC: $551.46(262.3)$ \\ $556.33(497.5)$ \\ Čedomir Benac \& Josip Rubinić \& Nevenka Ožanić: The origine and evolution of coastal and submarine springs in Bakar Bay}

The paper presents coastal and submarine springs in Bakar Bay. The northeastern coast of Bakar Bay is abound in springs, since there is the lowest placed contact between large karst aquifer and flysch lithogenetic complex which forms hydrogeological barrier. Studied area is situated between Črno and Žminjca locations, where water flows out in series of concentrated coastal and submarine springs as well as on the places of a diffuse outflow. A rapid raise of sea-level from the end of the Pleistocene changed the hydrogeological conditions so that coastal springs were submerged and new ones, at higher levels appeared. Some of submerged springs continued to throw out water, that is, they started to function as submarine springs (vrulja) due to a strong inflow from the background and high pressures. Some of them were not registered, although according to water balance analyses of wider area, widespread evidences of groundwater outflow could be expected. Their position reflects geological fabric of the area. Groundwaters have intensive flowing gradient. Their flowing out in hydraulically unstable zone have facilitated mixing of sea- water and fresh-water and as a result spring-water is usually brackish.

Key words: coastal spring, submarine spring, sea-level change, Adriatic Sea.

Izvleček

UDK: $551.46(262.3)$

$556.33(497.5)$

\section{Čedomir Benac \& Josip Rubinić \& Nevenka Ožanić: Nastanek in razvoj obalnih in podmorskih izvirov v Bakarskem zalivu}

Članek obravnava obalne in podmorske izvire v Bakarskem zalivu. Največ izvirov je ob severovzhodni obali zaliva, kjer je najnižji del kontakta med kraškim vodonosnikom in flišem, ki predstavlja hidrogeološko bariero. Študijsko območje obsega obalo med Črnim in Žminjco, kjer voda izteka koncentrirano v nizu kraških izvirov in difuzno na večih območjih. Ob dvigu morske gladine ob koncu pleistocena so nekateri obalni izviri prešli pod gladino, pojavili pa so se tudi novi, višji izviri. Veliko podmorskih izvirov ni poznanih, vendar na njihov obstoj kaže študija vodne bilance. Zaradi velikega hidravličnega gradienta veliko podmorskih izvirov deluje kot vrulje. Mešanje morske in sladke vode v hidravlično nestabilnem območju je vzrok, da je voda iz teh izvirov po večini brakična.

Ključne besede: obalni izviri, podmorski izviri, nihanje morske gladine, Jadransko morje. 


\section{INTRODUCTION}

On the coast and submarine of Kvarner we can frequently find submarine and coastal karst springs. In spite of long-term hydrological and hydrogeological investigations some of them are not even registered. Even the way they flow out is not well known. According to hydrological balances, those are the undetected places where probably large quantities of groundwater flow out in the sea. A reason for that often is a complicated and not well known position of water-permeable and impermeable rocks. The other reason is a fact that locations of submarine springs were investigated strictly from dry-land side. In that particular case they didn't use modern geophysical methods which are now common in geological and sea-bottom investigations (Jones 1999), and also can be used in Adriatic Sea area (Benac et al. 2002).

Bakar Bay is one of the areas which is abound in coastal and submarine springs. Relatively large karst background, which extends all the way to Gorski kotar mountains, is draining off to the Bakar Bay area thanks to a flysch rocky complex position, which presents regional hydrogeological barrier (Fig. 1). This area accumulates the highest amount of precipitations in

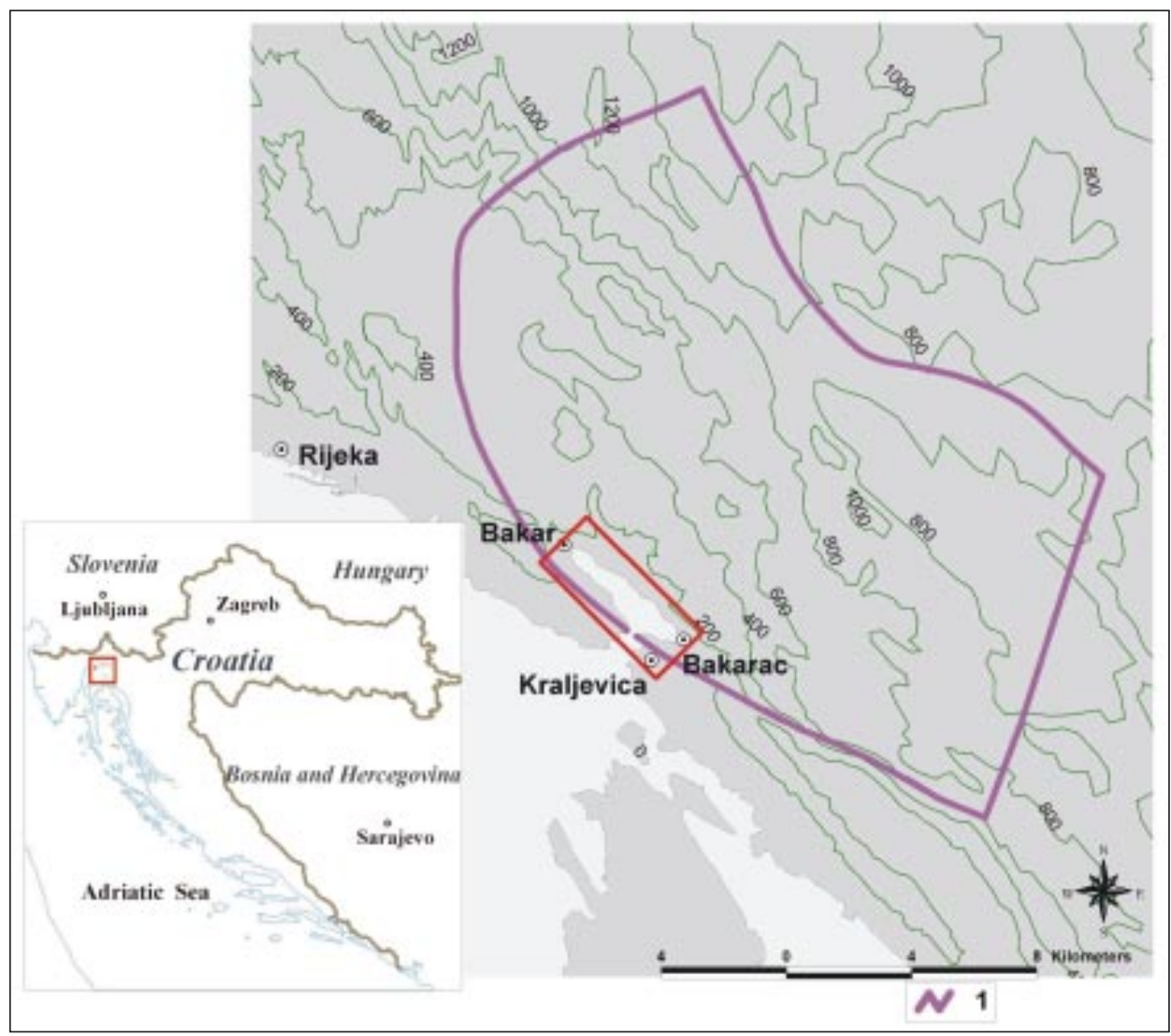

Fig. 1: Location map and catchment area of Bakar Bay. 1-boundary of the catchment area. 
Republic of Croatia. That is the reason why Bakar Bay is the area of the biggest concentration of springs on the Croatian coast (Biondić et al. 1996).

The springs of Bakar Bay can be divided in two groups. In the northwestern part of the bay, around the city of Bakar, single springs of higher capacity can be found: Perilo, Jaz, Podbok, Dobra and Dobrica, as well as abstraction gallery Perilo. In the southeastern part of the bay, between Črno and Žminjca locations, a larger number of smaller coastal and submarine springs (vrulja) can be found, as well as locations with groundwater diffuse drainage that are not intaken and are not being used for water supply.

Coastal and submarine area of location between Črno and Žminjca, mentioned above, haven't been under any significant engineering constructions, with the exception of an embankment of an old local and regional road. Those micro locations are thought to be good example of a close connection between geological composition and position of coastal and submarine springs due to insignificant changes of their hydrogeological conditions. It would be interesting to know the way

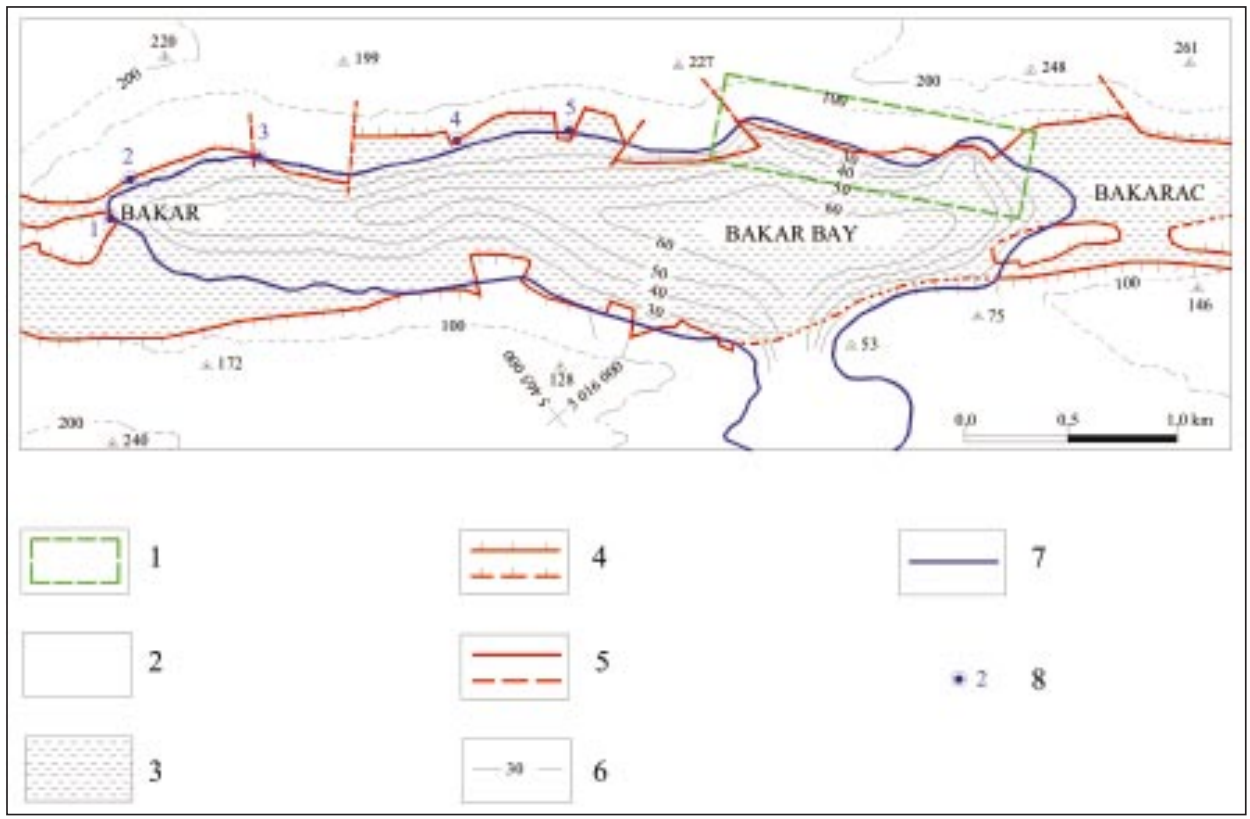

Fig. 2: Generalized geological map of Bakar Bay (presented without Quaternary deposits).

1-studied area

2-Upper Cretaceous and Paleogene carbonate rocks (permeable)

3-Paleogene flysch rocks (impermeable)

4-reverse fault, discovered or supposed

5-strike-slip fault, discovered or supposed

6-isobaths of basis of Quaternary deposits

7-recent coastline

8-important karst springs: 1-Perilo; 2-Jaz, 3-Podbok, 4-Dobra, 5-Dobrica. 
morphological evolution of Bakar Bay and Kvarner area reflected on hydrogeological conditions of the coast due to a fact that the coastal karst springs are in a sensitive hydrodynamical equilibrium state (Bonacci 1987). The second point of this paper is to find a connection between sealevel oscillation of Adriatic Sea during Late Pleistocene and Holocene, and spring position and its capacity changes as well.

\section{GEOLOGICAL DESCRIPTION}

Bakar Bay with Sušačka Draga valley in the north-west, and Vinodol valley in the south-east make a morphological unit and the bay itself is its lowest and submerged part (Fig. 1). The Bakar Bay depression is elongated and has broken striking in NW-SE direction. Deep slopes are sharply dividing it from the north-west and south-east risings. It is seperated from Sušačka draga valley in north-west by a pass at Sv. Kuzam and from Vinodol valley in south-east by a pass at Križišće. The Bakar Bay aquatorium itself has an irregular eliptic shape. It is $4700 \mathrm{~m}$ long and 600 to $800 \mathrm{~m}$ wide. $300 \mathrm{~m}$ long Bakar Strait joins it with the bay of Rijeka. Submarine slopes are steep on north-east and south-west, and the bottom is spread evenly. The highest depths of the bay reach 30 to $38 \mathrm{~m}$ and at the entrance $44 \mathrm{~m}$. The surrounding highest points go over $200 \mathrm{~m}$ high above the sea-level (Fig. 2).

Bakar Bay area is of a complex geological composition. It consists of lithologically very diverse sedimentary rocks that belong to the Upper Cretaceous period: rudist limestones; to the Paleogene: foraminiferal limestones and flysch; and to the Quaternary: coherent to noncoherent sediments of different origins (Šušnjar et al. 1969). Impact of the stress in the northeastern direction has caused Cretaceous and Paleogene rocks to fold, after which reverse faults and thrust faults were formed (Prelogović et al. 1981). That happened in older tectonic phase occurring at the end of the Paleogene period. That is the reason why tectonic structures and surrounding ridges are parallel and have general direction of striking in the NW-SE.

The older tectonic structures were disturbed, thanks to a change of direction of the regional stress from the north-east to the north. Effects of deformation are the most visible where carbonate rocks and flysch are in contact. That is a reason why relatively rigid carbonate rocks were pushed in the softer flysch rocks (Fig. 2).

The origin of Bakar Bay was probably conditioned by accelerated subsidence of that part of Vinodol depression, being a central zone of a shallow continental subduction (Blašković 1999), with simultaneous lifting of the area around St. Kuzam in the north-west and Križišce in the south-east of a bay.

Rocky ridges, sorrounding Bakar Bay, are formed in rudist limestones and dolomitic limestones of the Upper Cretaceous period. On the higher parts of slopes, paleogene foraminiferal limestones can be seen. Bottoms of the valleys and depression of Bakar Bay itself is formed in the paleogene flysch. Rocky elevations around Bakar Bay are often without a cover, and landscape has tipical karst scenery. On the steep slopes around the bay talus deposits can be seen. Flysch bedrock is covered by clayey weathering zone and slope deposits. Reverse faults between limestones and flysch rocks are usually covered by slope deposits (Kleiner et al. 1968; Magdalenić et al. 1992).

Alluvial deposits cover relatively small and flat areas around Bakarac and partly sea-bottom 
in the northeastern part of the bay. Alluvium is mostly holocene and it consists of pebbles, gravels and sand. The bottom of Bakar Bay is completely covered by recent sediments: fine sandy mud up to $10 \mathrm{~m}$ thick, and in some places even more. Submarine slopes are partly covered with rocky fragments or with coarse grained sand (Benac 2001).

Present diversity of the land and submarine relief of Bakar Bay is a result of lithological composition, transformation of the existing and formation of the new structures as well as geomorphological processes (Benac 1996). Morphological distinctions of the relief and a structural system of sediments as well as clearly noticeable seismicity are indicating a very intensive recent tectonic activity (Prelogović et al. 1995).

\section{HYDROGEOLOGICAL CONDITIONS}

A basic hydrogeological characteristic of Bakar Bay area make two lithogenic rock complexes which are also two contrasting environments of specific genesis and dynamics of surface and groundwater. These are:

- permeable carbonate rock complex;

- impemeable flysch rock complex.

Quaternary and recent deposits on the land and sea bottom have relatively small thickness and are restricted in spreading. This is a reason why they have an insignificant impact on dynamic of groundwater around Bakar Bay.

Entire north and northeastern part of Bakar Bay, from Bakar to Bakarac, is abound in water springs. Catchment area of these springs consists of a wide karst background which is composed of permeable carbonate rocks of the Jurassic, Cretaceous and Paleogene periods. That area has about of $230 \mathrm{~km}^{2}$ and extremely large amount of precipitation, up to $3000 \mathrm{~mm}$ on average. To the west it shares border with Zvir, Martinščica and Grobničko polje catchment areas, and to the east with Novljanska Žrnovnica catchment area (Biondić 2000).

In the catchmant area, carbonate rock complex is a collector of groundwaters. Within carbonate rocks a water dynamic is very complex and occurs in a deep karst underground. Groundwater movement is different on each location and depends on the position of water-permeable and impermeable rocks. A flow of groundwater is directed by very karstified fault zones. Filling up and draining of karst aquifer depends on climatic and meteorological conditions, that is, on amount and distribution of precipitation in hydrologic cycles.

Tectonic relationships, determined mainly by fault contact of flysch and carbonate complex, have strong influence on groundwater movement in lower part of catchment area and they determine its south-west border. In the largest part of striking, flysch complex is a barrier to groundwater flow so the springs often occur when in contact with carbonate complex (Biondić \& Dukarić 1993).

Groundwaters flow out in the northeastern part of Bakar Bay whether at coastal springs of a large capacity, or dispersed at spring zones and numerous submarine springs (vrulje). The outflow of water usually occurs next to faults between carbonate and flysch complex, and is partly determined by backwater activity of the sea. That is the reason why the north and northeastern side of Bakar Bay have numerous coastal and submarine springs. It is considered that groundwaters flow out from footwall structures which are connected with retentions in karst 
aquifers by deep systems (Biondić 2000). Water flows out under backwater activity of sea where footwall block of structural forms is submerged. Total estimated minimal capacity of all springs in Bakar Bay is approximately $0.8 \mathrm{~m}^{3} \mathrm{~s}^{-1}$ (Anon 1994). According to the latest hydrological analysis results, total average yearly balance contribution of the area is estimated at approximately $10 \mathrm{~m}^{3} \mathrm{~s}^{-1}$ (Anon 2002).

The northwestern coasts of Bakar Bay are a part of relatively small and enclosed catchment areas of Kostrena and Kraljevica which are completely separated from carbonate background in the north-east by a flysch barrier. Therefore, springs are periodical, of small capacity and usually brackish (Biondić \& Dukarić 1993).

Springs between Bakar and Črno are mostly water fed from a karst retention area in the northwestern part of the catchment area, which is proved by water tracing. In that area, significant

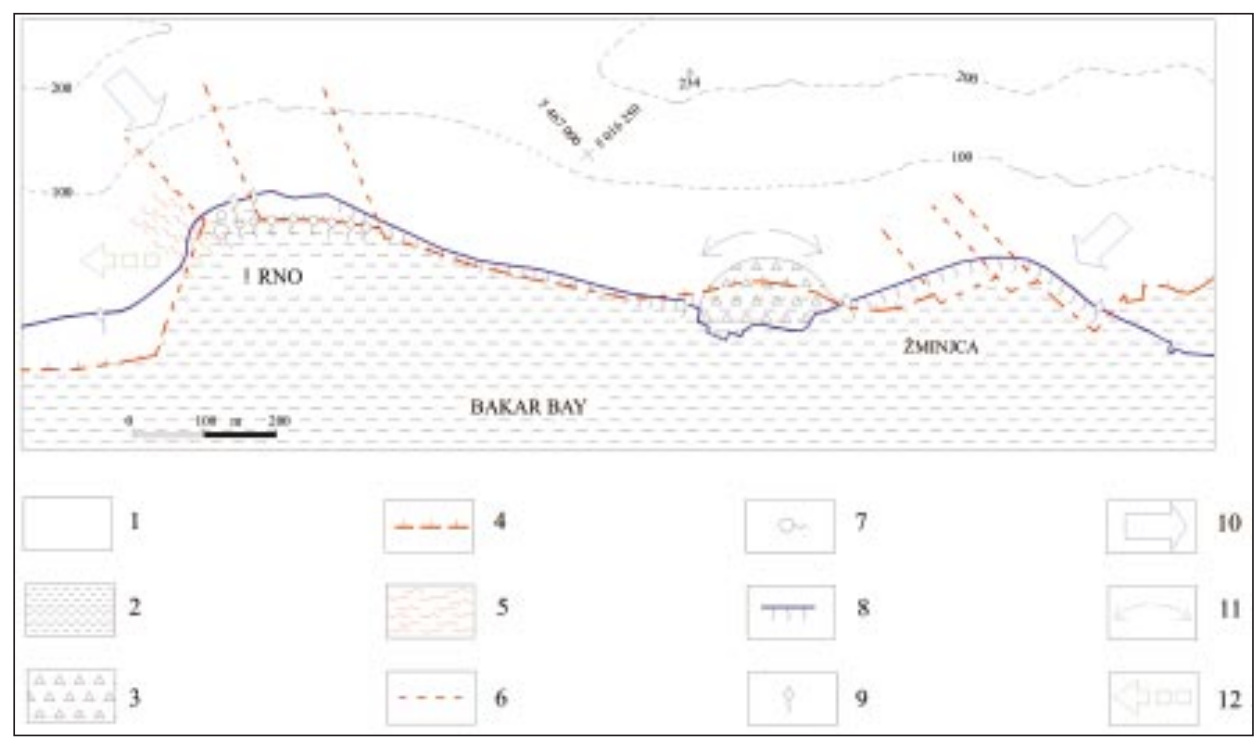

Fig. 3: Hydrogeological map of the studied area.

1-Upper Cretaceous and Paleogene carbonate rocks (permeable)

2-Paleogene flysch rocks (impermeable)

3-tectonic breccia

4-reverse fault

5-fault zone

6-strike-slip fault

7-submarine spring (vrulja)

8-coastal spring zone (mostly diffuse drainage)

9-higher capacity spring

10-main grounwater flow

11-local groundwater divide

12-possible flow of brackish water. 


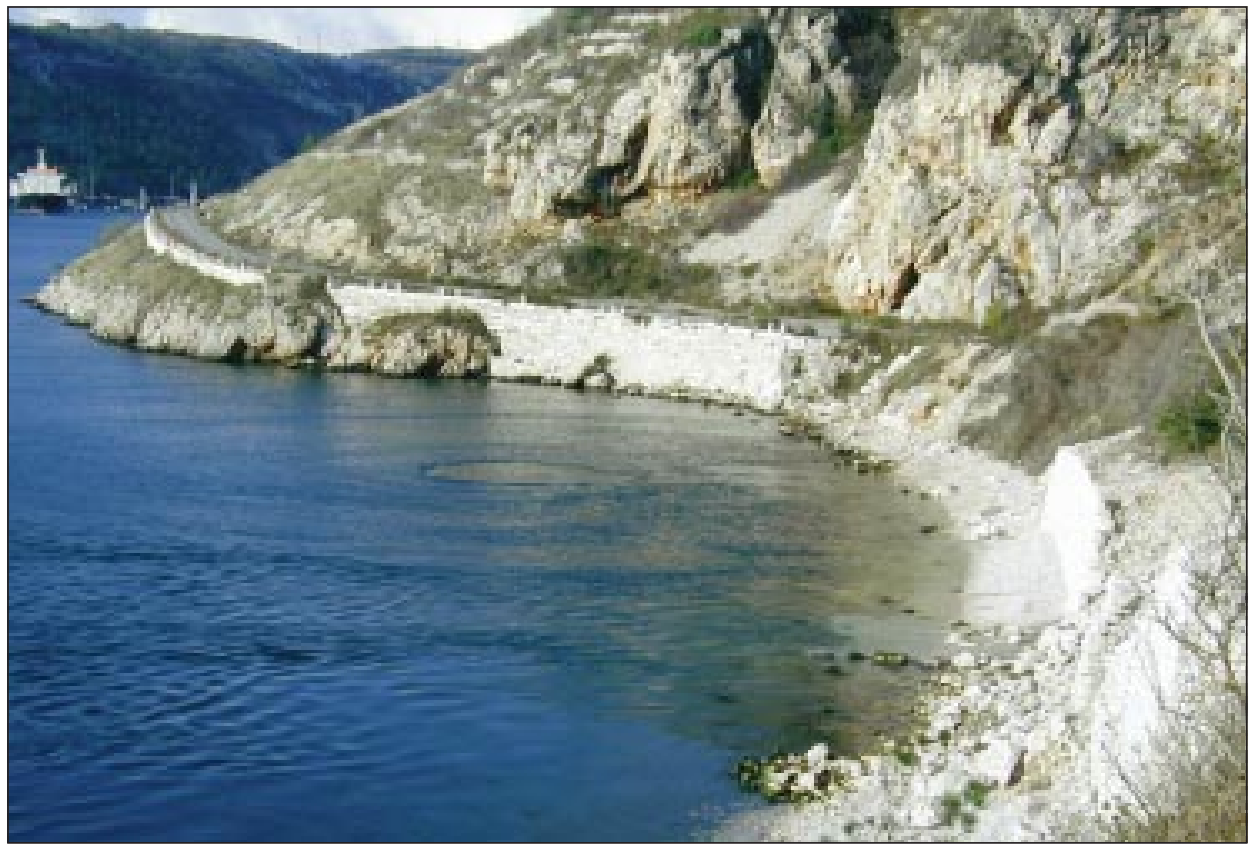

Photo 1: Črno location.

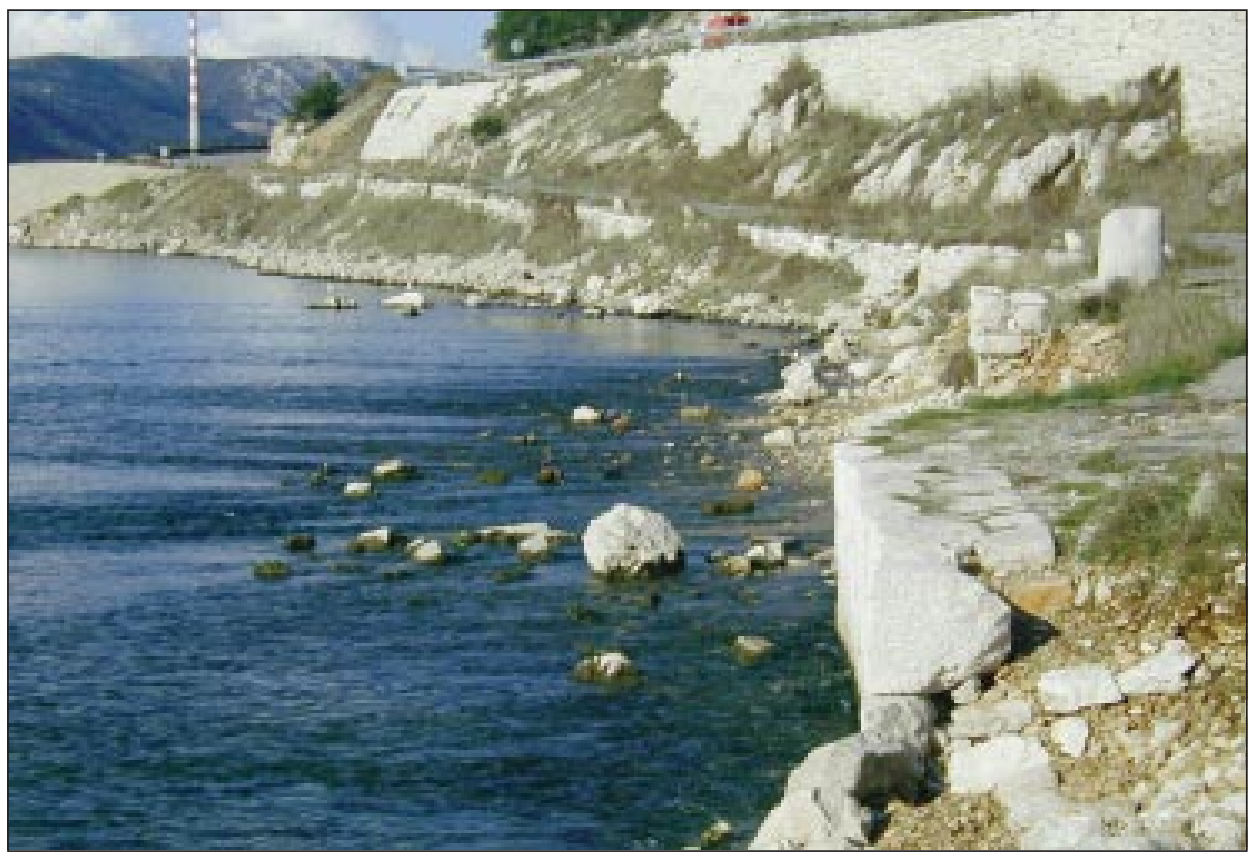

Photo 2: Žminjca location. 
changes of hydraulic gradient, from Grobničko polje level, across Ponikve to sea-level, can be observed. In Ponikve, which is located $3 \mathrm{~km}$ north from Bakar, during the long rainy periods, groundwater-level can be higher than $120 \mathrm{~m}$ in comparison to minimum recorded levels during dry periods (Anon 1987). Structural position of flysch and carbonate rock complex enabled the outflow of water to be mostly concentrated on few springs: Perilo, Jaz, Podbok, Dobra and Dobrica, of which the last two were intaken and are, like abstraction gallery Perilo, used for water supply of a larger area.

Coastal and submarine springs (vrulja) from Črno location to Bakarac are fed from the northeastern part of the catchment area. Very variable capacity of these springs shows that retention abilities of this part of catchment area are lower than the one in the north-west. Submarine springs can be occasionally seen in Črno location and relatively vast spring zone is located at Žminjca. These springs are not intaken nor used for water supply being often brackish due to hydrogeological flysch barrier partly showing up some ten meters under the sea-level.

An interesting example of coastal and submarine springs emerging is visible between Črno and Žminjca location (Fig. 3). In the middle of Črno location only one submarine spring is usually visible, and even this one appears periodically. However, starting with cape Križ and going to Črno in the north-west, during a large inflow to the surface of a calm sea, a whole range of linearly arranged coastal and submarine springs can be seen. This phenomenon can be rarely visible, except during large inflow as mentioned above. This series ends with a submarine spring of the highest capacity (Photo 1). This arrangement of coastal and submarine springs has probably resulted from the positioning of fault contact between flysch as a footwall block and limestone as a hanging wall block. It is considered to be a zone of communication between sea and karst aquifer from which the springs around Bakar are fed and a reason why they are periodically brackished (Anon 1994; 1997). This hypothesis is based on a piezometer level analysis of the Črno location background.

However, during repeated surveys of submarine slopes in Črno cove, using scuba-diving equipment, a continued diffuse outflow of water has been noticed, and this can be seen even after longer dry periods on lower temperature of water in reference to surrounding sea water.

On cape Križ, between Črno and Dobra locations, only one spring is visible, although carbonate rock mass is intensively crushed and karstified. The reason why is a hypsometrically higher placed fault contact between flysch and limestone rocks, which is covered by fault breccias and is hardly visible. Structural form as such has a function of a local groundwater-divide so water flows are directed to Črno in north-west and to Žminjca in south-east (Fig. 3). In Žminjca, a fault contact between flysch and carbonate complex, reaches a depth of $45 \mathrm{~m}$ under the sea-level, according to the results of drilling and geophysical surveys. Nowadays, this contact is covered with thick recent deposits. These deposits form a backwater so water flows out in relatively wide spring zone with the sea-level (Photo 2).

\section{MORPHOLOGICAL EVOLUTION OF THE STUDIED AREA}

At the peak of the Riss-Würm interglacial age, before some 135.000 to 120.000 years ago, global sea-level was similar to the present one. After that, gradual lowering of the sea-level up to $-125 \mathrm{~m}$ followed, some 25.000 years ago. So, in a relatively long period of 90.000 years, accord- 
ing to climatic oscillations, sea-level fluctuated with the amplitudes of 20 to $30 \mathrm{~m}$, going at least in two occasions up to 50 or $60 \mathrm{~m}$ below present sea-level (Chappell \& Shackleton 1986). Following these oscillations, sea level of Adriatic sea was changing too (D’Ambrosi 1969; Segota 1982; Prelogović \& Kranjec 1983; Brambati 1990).

Bottom of Rijeka bay became a local erosion base due to a retreating of sea. Undercutting of streams was particularly distinctive. Channels of the ancient streams in Martinšćica cove and on Rječina rivermouth, in the north coast of Rijeka bay, are cut in a rocky bedrock up to $60 \mathrm{~m}$ deep. (Benac 1996). Two abrasion terraces, recently covered with younger sediments, are evidence of a sea stagnation during the Würm. They have been determined in the north part of Rijeka Bay at the depth of 50 to $60 \mathrm{~m}$ (Benac \& Juračić 1998).

Erosion of the slopes and bottom of Bakar Bay has increased intensively by sea-level lowering. In the northeastern part of the bay, torrential stream named Bakarački rov eroded bottom of the valley. Because of a displaced coastal line, terrigenious sediments have been deposited far from recent coastal line. That could explain the position of prolluvial deposit in the northeastern

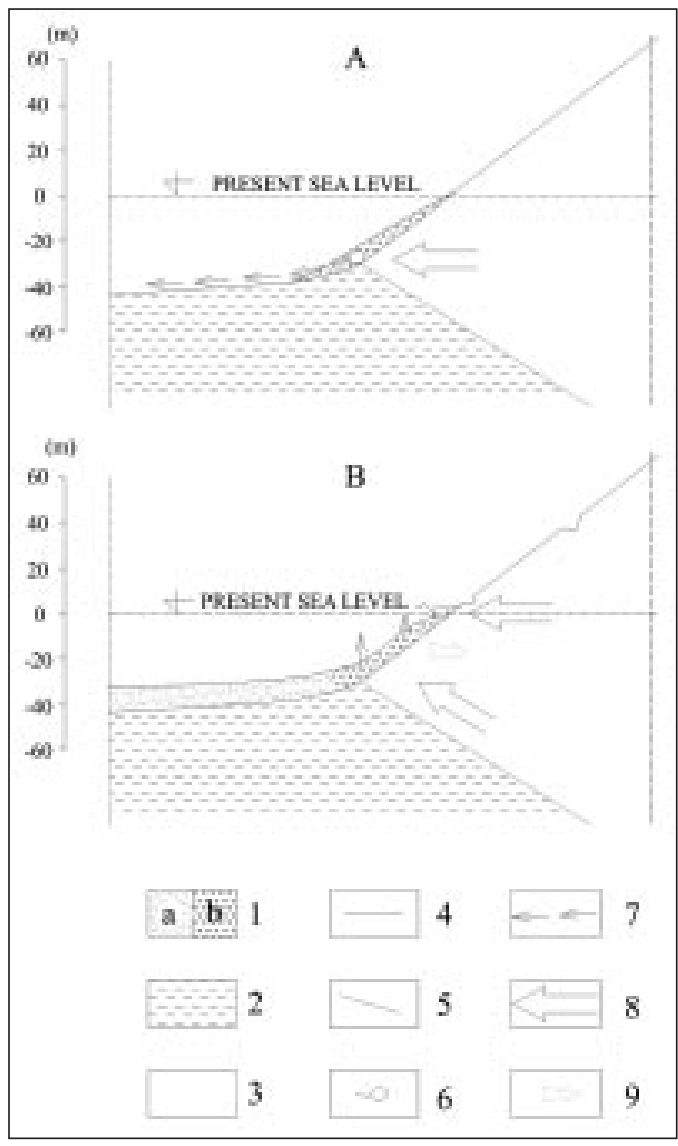

Fig. 4: Hydrogeological evolution of Črno location.

A-terrestrial conditions (90 -10 ka B.P.)

$B$-recent coditions

1-Quaternary deposits:

a-marine sediments (silty sand);

b-slope deposits (rocky fragments);

2-Paleogene flysch rocks (impermeable) 3-Upper Cretaceous and Paleogene carbonate rocks (permeable)

4-geologic boundary

5-reverse fault

6-spring

7-superficial flow

8-groundwater flow

9-possible brackish water flow. 
part of Bakar Bay, far from recent coastal line. Water-flows, formed by flowing out of the numerous springs in the northeastern part of the bay, were probably flowing through Bakar Strait towards lower situated lakes in present Rijeka Bay.

More geomorphological indications of the lower sea-level in Bakar Bay were discovered by drilling. On today submerged parts of coastal slopes, talus material can often be found. A reddish colour of its matrix is a clear sign that they have been formed in terrestrial conditions. A base for the holocene sediments in Bakar Bay was determined at the depth of $50 \mathrm{~m}$ under a recent sealevel (Fig. 2).

In Crno location, a major part of water from the northwestern part of the catchment area could flow to the present cove, while the present major karst springs in the north-west either didn't exist or their capacity was lower (Fig. 4). Therefore, if brackish water reaches from that micro location as far as Perilo gallery in the north-west, than during a lower sea-level an opposite process is possible. Crushed limestone rocks are visible in land and large caves are visible in submarine zone. In Žminjca, the deepest position of fault contact of flysch and limestone, is at $45 \mathrm{~m}$ under the sea-level. This was probably a level of flowing out of springs during lower sea-level in period between 90.000-10.000 B.P as well (Fig. 5).

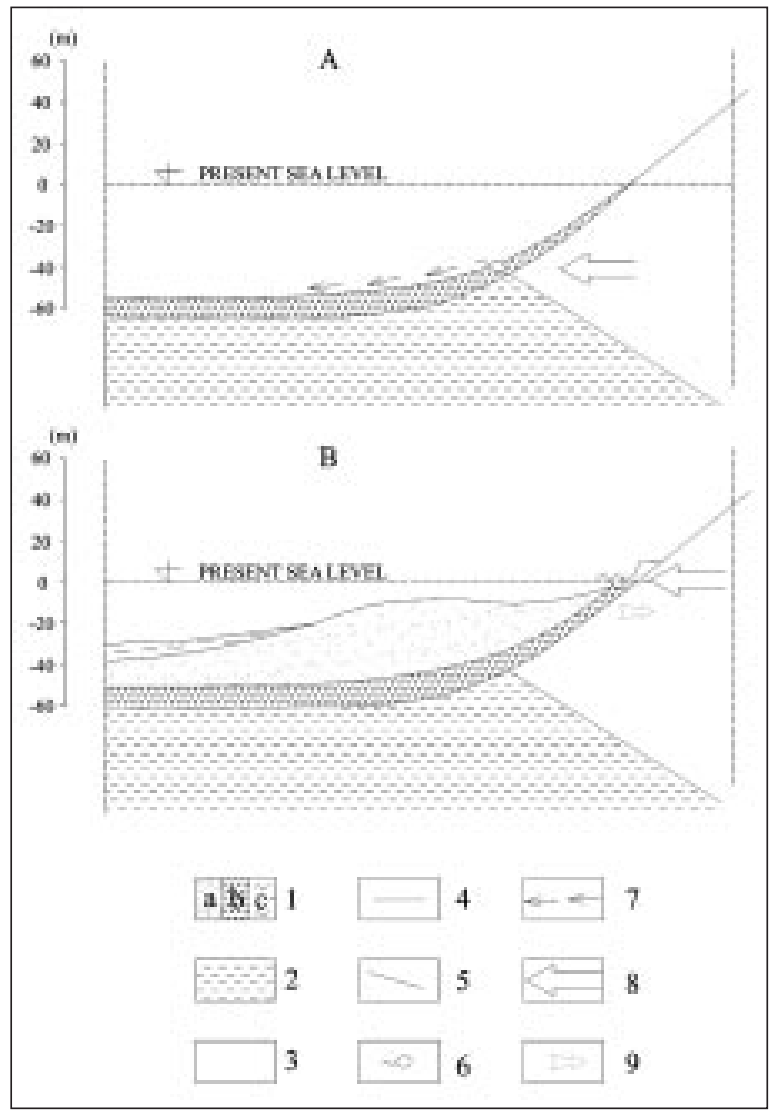

Fig. 5: Hydrogeological evolution of Žminjca location.

A-terrestrial conditions

(90 -10 ka B.P.)

$B$-recent coditions

1-Quaternary deposits:

a-marine and spring sediments (sand);

b-slope deposits (rocky fragments); c-marine sediments (mud);

2-Paleogene flysch rocks (impermeable)

3-Upper Cretaceous and Paleogene carbonate rocks (permeable)

4-geologic boundary

5-reverse fault

6-spring

7-superficial flow

8-groundwater flow

9-possible brackish water flow. 
Process of karstification on the islands of Kvarner is diverse depending on geological composition according to the last investigations (Božičević 1992). If we compare oscillations of Adriatic sea during the Würm glacial age with depths of karstifications, a compatibility between them can be found. A crushed zone of intensive karstification goes up to $-70 \mathrm{~m}$ deep on Krk and Cres islands (Benac \& Juračić 1998). In spite of a higher position, i.e. lower depth of flysch hydrogeological barrier, in Črno location, depth of karstification reaches 90 m under sea-level (Anon 1997).

Sea-level stagnation has caused groundwater-level stagnation in the coastal zone as well. This phenomenon could have caused formation of horizontal cave system. This way, submerged entrances of caves were discovered at the depth of 20 to $24 \mathrm{~m}$ : near Kostrena in the northern part of Rijeka bay, on the northeastern side of St. Marko island, between island of Krk and land; in Cavlena cove in the northwestern part of Krk (Benac \& Juračić 1998) and near Vrbnik, on the northeastern coast of Krk (Arko-Pijevac et al. 2001).

Along with lowering of global sea-level (Fairbanks 1989; Pirazzoli 1996) at the peak of the Würm, sea has completely retreated from the open part of the north Adriatic (Brambati 1990) and Kvarner (Benac \& Juračić 1998). In depressions of the bottom of Rijeka Bay at present, lakes have remained, where waters from Bakar Bay flew (Benac 1996).

Consequently, sea started to flood the north Adriatic (Colantoni et al. 1979; Correggiari 1996) and Kvarner area with a global sea-level rising. Hydrographic and sedimentation conditions similar to ones we have today, have developed during the Holocene. A slower sea-level rising in these locations has caused an opposite process: shallowing of the bottom and positive movement of the coastal line. This process was particularly noticeable on the rivermouths of rivers Raša, Rječina and Dubračina (Benac et al. 1992).

During the Holocene, sea-water flooded Rijeka bay first and then its outlying Bakar Bay. It is well-known that circulation of water in coastal karst area in Croatian part of Adriatic is in a sensitive equilibrium state (Breznik 1973; Bonacci 1987). Because of such rapid rise of sea-level, lowering of underground flow gradient was inescapable. It is quite possible that this has caused a complex mixing between fresh and salt-water in the flow-out zone (Custodio 1985). Coastal springs were submerged, and the new ones, on higher levels, were formed. Some of submerged springs continued to throw out water, that is, they started to function as submarine springs due to strong inflow from background and high pressures.

In conditions mentioned above, hydrogeological relations changed rapidly. However, development in Žminjca and Črno locations was different.

In Žminjca location rapid shallowing of the sea-bottom started with sedimentation of sand brought in by the springs as well as gravitational movement of talus deposits. Those sediments formed a backwater and consequently with its filling and sea-level rising, the level of spring zones rised (Fig. 5).

In Črno location, coastal springs were submerged too, and new ones, on higher levels, were formed. Some of the drowned springs continued to throw out water and started to function as submarine springs (vrulja) due to a strong inflow from the background and high pressures. Unlike in Žminjca, there was no significant sedimentation of sand brought by springs in this location. Rockfall and talus deposits have covered a part of the submarine slope, and therefore groundwaters drained diffusively (Fig. 4). 


\section{CONCLUSION}

The northeastern coast of Bakar Bay is abound in springs, since there is the lowest placed contact between large karst aquifer and flysch lithogenetic complex which forms hydrogeological barrier. In the northwestern part of Bakar Bay, springs of a larger capacity can be found (Perilo, Jaz, Podbok, Dobra and Dobrica). Since they have been used for water supply in longer period, they have been more investigated. Between Črno and Žminjca locations, water flows out in series of concentrated coastal and submarine springs as well as in places of a diffuse flow out. Some of them were not registered, although according to water balance analyses of wider area, widespread evidences of groundwater outflow could be expected. Their position reflects geological fabric of the area, that is, a relation between water-permeable limestone rocks and water-impermeable flysch rock complex.

Through the reconstruction of the origin of springs, we should take in consideration the oscillations of sea-level during the last 150.000 years. Terrestrial conditions in Bakar Bay existed for a relatively long period between 90.000 - 10.000 B.P., so springs were on different locations from the present ones. The highest concentrations of outflow were in Črno and Žminjca because of the lowest positioned contact of flysch and limestone. It is also possible that recently significant springs Perilo, Jaz, Podbok, Dobra and Dobrica were of lower capacity or even waterless.

Such rapid rise of the sea-level from the end of the Pleistocene and during the Holocene have caused lowering or even annulment of the underground flow gradients. In these conditions, hydrogeological conditions changed rapidly. Coastal springs were submerged and new ones, at higher levels, were formed. Some of the springs continued to throw out water, that is, they started to function as submarine springs (vrulja) due to a strong inflow from the background and high pressures. In Črno and Žminjca locations, groundwaters have intensive flowing gradient. Their flowing out in a hydraulically unstable zone facilitates mixing of sea-water and fresh-water and as a result spring-water is usually brackish. On these locations more water drains out under sealevel either concentrated on submarine springs or diffusively. That is confirmed by the latest hydrologic analyses of the water balance.

Higher level of flysch hidrogeological barrier facilitated to a more stable regime of flowing out at the springs in the northwestern part of Bakar Bay. Because of too much pumping of aquifer on those locations saltening of water happens periodically. Coastal brackish and submarine springs in Črno, could be a zone of two-way communication of fresh and brackish water between karst aquifer and sea. Therefore, further investigations should be directed on a final explanation of groundwater dynamics in Bakar Bay, especially in the context of long term influence of expected sea-level rising. Gathered experiences can be well used in investigations of other coastal springs.

\section{REFERENCES}

Anon, 1987: Hidrometrijski radovi-Rijeka. Vodoprivreda, Rijeka, 1987. (unpublished)

Anon, 1994: Zaštita kaptaže Perilo u Bakru od prodora mora. Hidrogeološka istraživanja. Institut za geološka istraživanja, Zagreb, 1994. (unpublished)

Anon, 1997: Izvorište Dobrica u Bakarskom zaljevu. Hidrogeološka istraživanja - zaštita od prodora mora. Instituta za geološka istraživanja, Zagreb, 1997. (unpublished) 
Anon, 2002: Vodnogospodarska osnova Hrvatske - Hidrološka studija za vodno područje primorsko-istarskih slivova. Hrvatske vode, Rijeka, 2002. (unpublished)

Arko-Pijevac, M. \& Č. Benac \& M. Kovačić \& M. Kirinčić, 2001: A submarine cave et the Island of Krk (North Adriatic Sea). -Natura Croatica 10, 3, 163-184.

Benac, Č., 1996: Morfološka evolucija Riječkog zaljeva: utjecaj klimatskih i glacioeustatičkih promjena. Acta Geographica Croatica, 31, 69-84.

Benac, Č., 2001: Geological and Geomorphological Features of Bakar Bay: Limitation on Urban Planning and Building. In: Regional Planning and Pilot Projects for Sustainable Development in Croatia (M. Crnjar \& G. Campeol, eds.). UNESCO Regional Bureau for Science in Europe (UVO-ROSTE) and Županijski zavod za održivi razvoj i prostorno planiranje., 189-195, Venezia-Rijeka.

Benac, Č. \& Ž. Arbanas \& B. Jardas, 1992: Morphogenesis and Evolution of the River Mouths in the Kvarner Area. -Proceedings of International Symposium Geomorphology and Sea, Mali Lošinj 1992, 37-45, Prirodoslovno-matematički fakultet, Zagreb.

Benac, С̌. \& M. Juračić, 1998: Geomorphological indicators of the sea level changes during Upper Pleistocene (Würm) and Holocene in the Kvarner region. -Acta Geographica Croatica 33, 27-45.

Benac, Č. \& M. Andrić \& R.Crmarić, 2002: Primjena modernih metoda u geotehničkom istraživanju jadranskog podmorja. -Priopćenja 3. Savjetovanja HUMTGI: geotehnika kroz EUROCODE 7, Hvar, listopad, 2002, 433-440, Hrvatska udruga za mehaniku tla i geotehničko inženjerstvo, Zagreb.

Biondić, B., 2000: Karst groundwater protection: the case of the Rijeka region, Croatia. -Acta Carstologica, 29, 1, 33-46.

Biondić, B. \& F. Dukarić, 1993: Vodni resursi općine Rijeka. -Hrvatske vode, 3, 185-190.

Biondić, B. \& A. Šarin \& F. Fritz, 1996: Hidrogeološka karta jadranskog sliva (Hydrogeological map of adriatic catchment area). Institut za geološka istraživanja, Zagreb.

Blašković, I., 1999: Tectonics of Part of the Vinodol Valley Within the Model of the Continental Crust Subduction. -Geologia Croatica, 52, 2, 153-189.

Bonacci, O., 1987: Karst Hydrology. -Springer-Verlag, pp. 180, Berlin-Heidelberg.

Božičević, S., 1992: High Frequency of Subterranean Karst Phenomena as an Indicator of Karstification Process on the Adriatic Islands. -Proceeding of the International symposium: Geomorphology and Sea, Mali Lošinj, September 1992, 111-114, Prirodoslovnomatematički fakultet, Zagreb.

Brambati, A., 1990: Origin and evolution of the Adriatic Sea. In: The Adiatic Sea: $25^{\text {th }}$ European Marine Biology Symposium (Colombo, G. ed.), University of Ferrara, 5-24, Ferrara.

Breznik, M., 1973: Nastanek zaslanjenih kraških izvirov in njihova sanacija. -Geologija: razprave in poročila, 16, 83-186.

Chapell, J. \& N.J. Shackleton, 1986: Oxigen isotopes and sea level. -Nature, 324, 137-140.

Colantoni, P. \& P. Galignan \& R. Lenaz, 1979: Late Pleistocene and Holocene Evolution of the North Adriatic Continental Shelf (Italy). -Marine Geology, 33, M 41-M 45.

Correggiari, A. \& M. Roveri \& F. Trincardi, 1996: Late Pleistocene and Holocene evolution of the north Adriatic Sea. -Il Quaternario. Italian Journal of Quaternary science, 9(2), 697-704. 
Custodio, E., 1985: Saline intrusion. Hydrogeology in the service of man. Memories of the $18^{\text {th }}$ Congress of the IAH, 65-90, Cambridge.

D’Ambrosi, C., 1969: L'Adriatico nel Quaternario. Atti del Museo Civico di Storia Naturale, 26(5), 129-175.

Fairbanks, G.R., 1989: A 17.000-year glacio-eustatic sea level record: influence of glacial melting rates on the Younger Dryas event and deep ocean circulation. -Nature, 324, 637-642.

Jones, E.J.W., 1999: Marine Geophysics. -John Wiley \& Sons.pp. 350, Chichester.

Kleiner, I. \& E. Nonveiller \& Ž. Vulić, 1968: Fundiranje luke za rasute terete u Bakru. Građevinar, $20,8,229-240$.

Magdalenić, A. \& V. Jurak \& Č. Benac, 1992: Inženjerskogeološka problematika izgradnje luke u jugoistočnom dijelu Bakarskog zaljeva. -Pomorski zbornik, 30, 633-654.

Pirazzoli, P.A., 1996: Sea-level Changes. The last 20.000 Years. -John Wiley \& Sons, p.p. 210, Chichester-New York- Brisbane-Toronto-Singapore.

Prelogović, E. \& I. Blašković \& D. Cvijanović \& D. Skoko \& B. Aljinović, 1981: Seizmotektonske značajke vinodolskog područja. -Geološki vjesnik, 33, 75-93.

Prelogović, E. \& V. Kranjec, 1983: Geološki razvitak područja Jadranskog mora. -Pomorski zbornik, 21, 387-405.

Prelogović, E. \& V. Kuk \& D. Jamičić \& B. Aljinović \& K. Marić, 1995: Seizmotektonska aktivnost Kvarnerskog područja. Zbornik radova 1. Hrvatskog geološkog kongresa, Opatija 1995, 2, 487-490, Zagreb.

Šegota, T., 1982: Razina mora i vertikalno gibanje dna Jadranskog mora od ris-virmskog interglacijala do danas. -Geološki vjesnik, 35, 93-109.

Šušnjar, M. \& J. Bukovac \& L. Nikler \& I. Crnolatac \& A. Milan \& D. Šikić \& I. Grimani \& Ž. Vulić \& I. Blašković, 1970: Osnovna geološka karta, 1:100.000, list Crikvenica. Savezni geološki zavod, Beograd. 